\title{
Young adult consumers' media usage and online purchase likelihood
}

\section{Yolanda Jordaan* \& Lené Ehlers}

\begin{abstract}
OPSOMMING
Jong volwassenes (18 tot 24 jaar) het belangrike verbruikers in eie reg geword en gevolglik het hulle mediapersepsies en -verbruik belangrike vraagstukke vir bemarkers geword. Die houding en persepsies van jong volwasse verbruikers ten opsigte van tradisionele media soos gedrukte media, televisie en radio kon verander het vis-à-vis die koms van nuwe media tipes, alhoewel teenstrydige bevindinge hieroor geboekstaaf is. Die feit dat jong volwasse gebruikers met rekenaars groot geword het en die invloed daarvan op die gebruik van nuwe media soos die internet, skep geleenthede vir bemarkers om hulle media-mengsel aan te pas. In die lig hiervan is dit belangrik dat bemarkers jong volwasse verbruikers se mediagebruike verstaan ten einde hulle bemarkingsboodskappe effektief te versprei.
\end{abstract}

Die navorsing het ten doel om jong volwasse verbruikers se gebruik van tradisionele media teenoor nuwe media, sowel as die gebruik van gedrukte media versus die internet te bepaal. Die studie poog ook om te bepaal of internetkopers ' $n$ verhoogde waarskynlikheid toon om in die nabye toekoms aanlynaankope te doen, asook of aanlynaankope meer tot mans as dames sal spreek.

Die teikenpopulasie vir die studie het studente tussen die ouderdomme van 18 en 24 jaar by een van die grootste residensiële universiteite in Suid-Afrika ingesluit. 'n Geriefsteekproef het gelei tot die insameling van 1298 voltooide vraelyste.

Resultate dui daarop dat die mediaverbruik van nuwe media betekenisvol meer is as dié van tradisionele media. Verder word die internet meer dikwels gebruik as die lees van gedrukte media. Daar is ook betekenisvolle verskille gevind tussen jong volwasse verbruikers wat voorheen aanlynaankope gedoen het en dié wat nie ervaring daarvan het nie, met betrekking tot hulle waarskynlikheid om aankope via die internet in die nabye toekoms te doen. Laastens toon die resultate dat die waarskynlikheid van vroulike verbruikers om in die toekoms aankope deur middel van die internet te doen laer is in vergelyking met hulle manlike eweknieë.

Implikasies van die bevindinge is dat die wegbeweeg van tradisionele media na nuwe media met omsigtigheid benader moet word aangesien resultate nie ' $n$ beduidende tendens toon van ' $n$ wegbeweeg van tradisionele media na nuwe media nie. Verskille tussen manlike en vroulike respondente moet in ag geneem word by teikenmarkidentifisering en ontwikkeling van bemarkingstrategieë. Die opnamemetode van geriefssteekproeftrekking in die studie is beperkend tot veralgemening na ander populasies en ' $n$ waarskynlikheidsteekproef word voorgestel vir toekomstige studies.

'n Soortgelyke studie word aanbeveel vir toekomstige navorsing vir die ouderdomsgroep 25 to 30 jaar oud om vas te stel of daar beduidende verskille teenoor die huidige studie voorkom. Die mediaboodskap is nie in hierdie studie aangeraak nie en toekomstige studies kan bepaal of die keuse van die medium (tradisioneel of nuut) verband hou met die tipe boodskap (oorredend, herinnering of bewustheid). Daar word ook aanbeveel dat navorsers die verwantskap tussen gebruikspatrone en die geloofwaardigheid van media tipes ondersoek. Vergelykende studies tussen ontwikkelende en ontwikkelde lande in terme van mediagebruik en persepsies kan ook van groot waarde wees.

\section{- Prof Y Jordaan*}

Department of Marketing and Communication Management

University of Pretoria

Tel: $+27(0) 124202997$

Fax: +27 (0)12362 5085

Email: yolanda.jordaan@up.ac.za

${ }^{*}$ Corresponding author

\section{- Dr L Ehlers}

Department of Marketing and Communication Management

University of Pretoria 


\section{INTRODUCTION}

Young adults (18 to 24 years) have increasingly become important consumers in their own right (Anderson et al, 2007) and their media usage has become an important issue for organisations and researchers (Host, 2005:1-5, King, 2006; Chan \& Fang, 2007; Kreutzer, 2009:1-8). This segment's growth in consumption power has compelled marketers and researchers into action. However, understanding young adult consumers poses various challenges because this generation grew up in a digital revolution era that had, and continues to have an impact on multiple areas of their lives. From how they seek out news information and entertainment, how they communicate with the world and each other, to the number of activities they do in one day. They are dubbed "digital natives" (King, 2006) and the challenge for brands, products and advertising will not only be to reach them, but also to create a fit with the mindset that resulted from the digital era and the fast-paced world it encourages.

Studying young adult's usage of new and traditional media will enable marketers to better understand the role of mass mediated messages in the lives of this expanding segment. Uncovering the latest usage trends will provide marketers with the opportunity to effectively reach this segment. This generation was the first to truly grow up with computers, the internet and cell phones, and consequently are very comfortable with these types of media (Fox, 2005; Szeto, 2005). They frequently use technology for socialising on, for example, Facebook, MySpace, email, sms or $\mathrm{MXit}$ and they expect and demand up-to-date technology, whether at home or at work (Youth Inc, 20002001; Farris et al, 2002; Berndt, 2007:4-5). They are thus fully fledged digital citizens which command an understanding of their changing media usage in order to effectively build a communication platform for them that will meet their changing needs and desires (King, 2006).

Due to the digital revolutionised era in which young adult consumers operate, the question now arises if this digitalised generation will also be more likely to purchase online because of their frequent use of media such as the internet? Attempts have been made to establish the relationship between media usage (specifically internet) and engagement or likelihood to purchase from the internet as a medium (Korgaonkar \& Wolin, 2002; Kilger \& Romer, 2007). This has led to other studies exploring gender differences and its influence on online purchase likelihood (Bakewell \& Mitchell, 2003; Janda, 2008).

The purpose of this paper is to explore the media usage behaviour of young adult consumers. It also investigates their likelihood to purchase online and whether online shopping appeals more to females than males. It should be noted that the purpose is not to explore media behaviour of young adult consumers in depth, but rather to gain a broad understanding of how often they use different media types. Findings will indicate if young adult consumers in South Africa emulate the media usage of their international coun- terparts, which will create a platform for future research on media behaviour. This study will provide marketers and decision makers with an indication of which media type/s to consider to effectively reach this market with their intended messages. The paper first provides background on media in general, followed by a basic description of traditional and new media. Thereafter likelihood to purchase online and related gender differences are put in perspective. Next, the research objectives and methodology are described, and the research results reported. This is followed by a discussion of the implications of the findings, as well as a brief conclusion highlighting the limitations of the study.

\section{LITERATURE REVIEW}

The term "media" used in this paper refers to the different types of mass media, which can be used to communicate and interact with a large number of audiences. Print was considered the first mass media channel, followed by recording, cinema and radio. Television emerged as the fifth channel during the 1950s, followed by the internet as the sixth channel after 1990. Around 2000 the cell phone has appeared as the seventh and latest mass media channel (Ahonen, 2008:211). From these media channels, the following were included in the study: traditional print media (magazines and newspapers), broadcast media (television and radio) and new media (internet and cell phones). The concepts of "old" or traditional and "new" media within the context of this study will now be explored.

\section{Traditional media}

Traditional media can be broadly categorised as print media, radio, television and outdoor advertising. Target audiences and especially the young adult segment (18 to 24 years) are exposed to a great deal of traditional media on a daily basis, ranging from television, to paper-based flyers and mail (Bakewell \& Mitchell, 2003). However, the effectiveness of this form of advertising media can be questioned as this group of consumers are seeking more creative and interactive media types.

Several inconsistent views exist as to the role and usage of traditional media by young adult consumers. With regard to print media, one study among young adults in Turkey and New Zealand reported that print media is considered to be important information sources and useful buying guides (Ashill and Yavas, 2005). On the other hand, a web survey among young Turkish consumers indicated that print media are less reliable sources compared to the internet (Calisir, 2003). It is reported that young adult consumers in South African cities spend more time interacting with friends via social networking sites, than being in front of the television (Newton, 2009).

As for print media, different views are also reported for broadcast media. Several studies have shown that young adult consumers find radio irritating, deceiving, uninformative and a bad source of product information, and that less time is spent listening to the radio 
than before (Calisir, 2003; Ashill \& Yavas, 2005). Other findings support the notion of a decline in the use of broadcast media and specifically report that the young adult segment ( $<25$ years) watches less prime time television than other adults (Youth Inc, 2000-2001; Calisir, 2003; Brier, 2004; Seock \& Chen$\mathrm{Yu}, 2007)$. Despite the reported decline in the use of broadcast media, several authors believe that radio, along with television, are effective in reaching the said age group and that these media types are still significant, and even increasing (Wolburg \& Pokrywczynski, 2001; Farris et al, 2002; Dotson \& Hyatt, 2005; Anderson et al, 2007).

According to Napoli and Ewing (1998:1669-1670), young adult consumers are indifferent with respect to their preferences to traditional media types versus new media types. Their research findings showed that the internet is unlikely to replace traditional broadcast media as consumers acknowledge their association and use with traditional media. These authors believe that traditional media has not necessarily declined in terms of usage by young adults, but rather in terms of their usage in finding information on specific brands that are important to them (Napoli \& Ewing, 1998:1660).

\section{New media}

The media landscape has changed significantly as new communication technologies have begun to compete with traditional ones. The classic ways of advertising have been changed by the escalation of computer and other communication technologies (Calisir, 2003). Media has created an environment where marketers have endless opportunities in terms of the new world of technology and new media to reach consumers (Napoli \& Ewing, 1998:1669-1670). The proliferation of media led to the expansion of marketing beyond the limits of traditional media such as television, into a digital media culture. Some refer to the new "marketing ecosystem" which includes cell phones, mobile music devices, instant messaging, video games and virtual, three dimensional worlds (Chester \& Montgomers, 2008).

Straubhaar and LaRose (2006:20) regard the defining aspects of new media to be digital (text, image and sound are combined in two-way channels), interactive (feedback from receiver is used by the source to continually modify message delivered to the receiver), audience generated (ability of audience to contribute content of their own), asynchronous (communication acts that are distributed over time), multimedia (modes of presentation) and narrow casted (dedicating communication channels to specific audience subgroups). For the purpose of this research, the new media types included in the study will be internet and cell phones.

One of the greatest appeals of new media for young adult consumers is the feeling of self-reliance when making media choices, as well as being able to use new media to make decisions on brand issues and decision making on products (Alch, 2005; Anderson et al, 2007; Berndt, 2007:5). Teens and young adults simultaneously consume multiple media, adding to the challenge for marketers to understand and harness all the new and proliferating media options available at present (Wyner, 2007).

Technology has progressively increased the speed and complexity of information communication as well as the way in which consumers have used this new media to obtain information (Berndt, 2007:5). Since the emergence of new media technologies, consumers have started using it to obtain information about products and services. Young adult consumers are subjected to many forms of media and brands from a very young age, making them more technologically knowledgeable (Kennedy et al, 2006:413-414; Berndt, 2007:5). It has been noted that the internet appears to be the medium of choice by young adult consumers, partly due to the fact that they have grown up using it (Dotson \& Hyatt, 2005). Findings from a study conducted among 14 to 22 year olds in the USA reported that using the internet to obtain information was the most popular form of media used by respondents (Pasek et al, 2006). It is stated by Fox (2005) that twelve to 28 year old internet users embrace online applications to communicate, to have creative uses and lastly, to have social uses.

Regarding new media types, some view that the cell phone is to become the most influential medium for marketing (Hanley \& Becker, 2008). Jin and Villegas (2008) state that "the mobile phone can be treated as a new multidimensional marketing communication technology used to fulfil well-understood needs in novel ways". This is reflected in the growth of popularity of cell phones with more than 800 million cell phones and other mobile devices in use worldwide (Jin \& Villegas 2008). In South Africa more than 60\% of all South Africans above the age of 16 own a cell phone (Kreutzer, 2009:3). Mobile phone technologies, including communicating via sms or MXit, are prominent among the young adult consumer group and have allowed them to stay in contact with friends and family (Youth Inc, 2000-2001; Farris et al, 2002; Berndt, 2007:4-5). High percentages of cell phone ownership are reported among young adult consumers, both locally and abroad (Berndt, 2007:10; Anderson et al, 2007).

A fondness of the mobile device is found among young adults because they access the internet and television via their cell phones. This generation has an inclination towards multi-tasking and the mobile device simplifies this action as it can be held in one hand while moving around (Crosman 2008). McCastland (2005) regard mobility as one of the main reasons why the cell phone is so important to young adult consumers. They have an intimate relationship with their phones and together with the personal computer it is regarded as the "most important piece of technology" that they own. The cell phone enables brands, businesses and marketers to engage and interact more intimately with their target audience. Young adult consumers regard their cell phones as more than just a means of voice communication. Cell phones can also provide entertainment, convey social status and assist in expressing individuality. This gen- 
eration is therefore sometimes labelled the "cellular generation".

The study of mobile usage, advertising and commerce is still in an early stage and poses a challenge to academics and practitioners (Jin \& Villegas, 2008). An analysis of cell phone usage may open new marketing and advertising opportunities to both users and marketers. The focus of this study is, however, not to gain an in-depth understanding of young adult consumers' cell phone user behaviour, but rather to gain an overview of media usage, including cell phones (as part of new media types).

\section{Likelihood to purchase online}

Online retailing is growing in popularity as more consumers worldwide are starting to use the internet to purchase products and services (Kim \& Stoel, 2005). The internet as a shopping channel is being explored by an ever-increasing number of young adult consumers, as indicated in a study conducted amongst USA college students (Seock \& Chen-Yu, 2007). Many believe that the internet is the medium of choice for young adults and has become intertwined with their culture (Youth Inc, 2000-2001; Farris et al, 2002; Dotson and Hyatt, 2005). This has led to an increase in online transactions from young adult consumers (Devaraj et al, 2006).

The internet has several advantages as a shopping channel: it provides shoppers with access to information on any product or service worldwide; it saves time; eliminates congestion and queues; and is interactive and anonymous (Du Plessis et al, 2004; Y Monsuwe' et al, 2004; Ashill \& Yavas, 2005; McClatchey et al, 2007). Findings from a US study indicated that young adults' buying habits are influenced more by the internet than any other media (Wolburg and Pokrywczynski, 2001). South African research has shown that the longer a person uses the internet, the more likely (s)he becomes to buy online (Du Plessis et al, 2004).

Young consumers are active on the internet and can be considered as the potential dominant users of online shopping activities in future. However, several factors might cause scepticism about online shopping. Xu and Paulins (2005) argue that clothing products are difficult to purchase online since consumers cannot touch, see or fit garments. Lack of social interaction is a disadvantage to those "leisure shoppers" who shop for fun and socialisation (Xu \& Paulins, 2005; Seock \& Chen-Yu, 2007). Security is another concern as people are hesitant to submit credit card details online (Xu \& Paulins, 2005).

It has been discussed that young adult consumers are more at ease using the internet than previous generations, and it follows that these consumers are likely to shop online (Moore \& Rodgers, 2005:4). Purchase likelihood in the context of this study refers to the probability that a young adult consumer will buy goods or services via the internet. It has also been suggested that likelihood to buy via the internet should increase as the use of the internet increases.
Familiarity that resulted from ongoing usage as well as past experiences with the internet should also have a positive influence on likelihood to purchase online. The "mere exposure effect" in which continuous exposure tends to increase people's liking for a given stimuli, can be used to explain this tendency (Kuhlmeier \& Knight, 2005). The study focuses on young adult consumers' online purchasing behaviour and how likely they are to purchase from the internet in the near future. The focus is thus on the relationship between internet usage and likelihood to purchase from the internet.

\section{Gender differences in online purchase likelihood}

Gender differences in online purchase behaviour have been the focus of several research studies (Akhter, 2003; Janda, 2008). Findings of these studies suggest that there is a difference between male and female consumers and their likelihood to purchase online. Akhter (2003) concluded that demographic characteristics such as gender, age, education and income significantly influence the likelihood of purchasing symphony tickets over the internet. The study was conducted among 3087 consumers in the US and found that males in contrast to female, younger people in contrast to older, more educated in contrast to less educated, and wealthier people in contrast to less wealthy, are more likely to use the internet to purchase tickets online. Another US study reported that female consumers' concern with privacy were negatively related to the likelihood of making online purchases, whereas male consumers' concern for loss of personal information was not related to making online purchases (Janda, 2008). Similarly, females' concern about credibility of online information had a strong negative effect on online purchase likelihood for them, but had no effect on the likelihood for males. The study suggested that these differences might be reflective of gender differences in risk perception, with women being more wary of potential online risks such as credit card misuse, fraudulent sites, privacy loss and shipping problems.

Another argument pertaining to the difference between gender groups in terms of shopping behaviour focuses on the shopping experience, rather than on risk perception. Bakewell and Mitchell (2003) state that females enjoy the process of shopping and are satisfied to spend a great deal of time and mental energy in shopping centres, as opposed to males who are more inclined to buy quickly and avoid it as much as possible. The internet may therefore provide males with a quick, convenient and easy to access shopping option. Males do not require the social aspect of shopping and consider shopping to be a task, rather than a social experience (Maciejewski, 2004).

Studies that investigated the role of gender in forming attitudes toward the internet and its shopping possibilities, established that females find the web more informative (Wolburg \& Pokrywczynski, 2001), while males are more interested in using different technologies during the shopping process ( $\mathrm{Y}$ Monsuwe' et al, 2004). 
$\mathrm{Xu}$ and Paulins (2005) mentioned that internet apparel shoppers are predominantly relatively young, educated females, but that the profile of internet shoppers increasingly resembles the population at large. Findings from a South African study determined that internet buyers are more likely to be male ( $\mathrm{Du}$ Plessis et al, 2004). There has also been some evidence that males receive slightly more media exposure per day than females (Dotson \& Hyatt, 2005).

In light of the conflicting evidence, it is difficult to conclusively deduce that males and females differ with regard to their frequency of media exposure and the likelihood to shop online (Akhter, 2003; Du Plessis et al, 2004; Y Monsuwe' et al, 2004; Dotson \& Hyatt, 2005; Janda, 2008). The focus of this study will therefore be to investigate the gender differences of young adult consumers in media usage and likelihood to purchase online. Although very relevant, an investigation of attitude differences among gender groups in terms of online shopping does not form part of this study.

\section{RESEARCH OBJECTIVES}

As outlined in the literature review, conflicting evidence exists about the media habits of young adult consumers (18 to 24 years age group). Also, limited evidence of previous studies conducted in South Africa exist that could provide a sound base of the media usage behaviour among young adults in South Africa. Furthermore, several inconsistencies have been found in recent related literature. Authors have contradicting viewpoints on the role and usage of new media amongst young adult consumers (Wolburg \& Pokrywczynski, 2001; Calisir, 2003; Dotson \& Hyatt, 2005; Anderson et al, 2007). The role that gender differences play in media usage of this segment is another area of debate, especially with regard to internet shopping and online shopping likelihood (Du Plessis et al, 2004; Y Monsuwe' et al, 2004; Dotson \& Hyatt, 2005; Xu \& Paulins, 2005).

One should also take into consideration that South Africa is a developing country and different trends may be applicable to young South African adults compared to those in developed countries. In a comparative study by Weldon (2009), the South African youth showed a typical emerging market teen profile (reporting distinct differences in terms of interaction with media), although in certain respects, the South African youth think and behave more like developed market teens (in terms of cell phone penetration).

From the findings reported in the literature review (mainly from international studies), the objectives for this study are four-fold: 1) to determine traditional versus new media usage amongst young adult consumers; 2) to determine internet versus print media usage amongst young adult consumers; 3 ) to measure young adult consumers' likelihood to shop online; and 4) to investigate gender differences with regard to online shopping likelihood.

The following hypotheses (null and alternative) were formulated to address the research objectives:
$\mathrm{H}_{0}$ : Young adult consumers do not use new media more frequently than traditional media.

$\mathrm{H}_{1}$ : Young adult consumers use new media more frequently than traditional media.

$\mathrm{H}_{0}$ : Young adult consumers do not browse the internet significantly more frequently than they read print media.

$\mathrm{H}_{2}$ : Young adult consumers browse the internet significantly more frequently than they read print media.

$\mathrm{H}_{0}$ : There is no significant difference between young adult consumers who have shopped online and those who have not shopped online with regard to their likelihood to purchase online.

$\mathrm{H}_{3}$ : There is a significant difference between young adult consumers who have shopped online and those who have not shopped online with regard to their likelihood to purchase online.

$\mathrm{H}_{0}$ : Young adult male and female consumers do not differ significantly in their online purchase likelihood. $\mathrm{H}_{4}$ : Young adult male and female consumers differ significantly in their online purchase likelihood.

\section{METHOD}

The research approach can be classified as a formal, ex post facto study due to the fact that hypotheses will be tested without manipulating or controlling to test a cause-effect relationship. The study is descriptive in nature as respondents will be asked how often they use which type of media. It is also crosssectional as it represents a "snapshot of one point in time" as respondents are only interviewed or asked to complete the questionnaire once. Detail on the sampling, data collection, measurement instrument and data analysis follows.

\section{Sampling}

The population was all undergraduate and postgraduate students in any year, with a maximum age of 24 , registered at the largest residential university in South Africa during 2008. Convenience sampling was used because of its cost effectiveness and ease to conduct. Worth noting is the fact that other researchers have conducted similar research among students in similar contexts (Mangleburg \& Bristol, 1998; Moore \& Rodgers, 2005:10; Berndt, 2007:5). The target population for the study consisted of students who were registered in the following faculties: Economic and Management Sciences; Education; Engineering, Built Environment and Information Technology; Law; and Natural and Agricultural Sciences.

\section{Data collection}

A survey questionnaire was used to collect the data and no incentives were offered to respondents to participate in the study. The data collection instrument was pre-tested among 30 respondents who formed part of the target population. During the pre-testing, individual respondents were asked to complete the questionnaire and indicate any problems. A few respondents were unsure whether they should com- 
plete the area indicating "Respondent number". Consequently the questionnaire was adapted to clearly indicate that "Respondent number" was for administrative purposes only. Respondents were intercepted on the main campus of the particular university during a three-week period in September 2008 by a team of ten fieldworkers. Fieldworkers explained the purpose of the survey and when the respondent indicated his/ her willingness to participate, the questionnaire was handed over for completion. A total of 1298 questionnaires were completed and used for data analysis.

\section{Measurement instrument}

The measurement instrument consisted of three sections and was only available in English. Section A measured frequency of media usage across six media types. The frequency questions were adapted from the questions used in a national survey in 2007 by the South African Broadcasting Corporation (SABC) (2007:32-37). The adaptation included fewer media types than the original survey (since the study focused on fewer media types). Respondents were asked how frequently they watch television, listen to the radio, read a magazine, read a newspaper, browse the internet, and use a cell phone. The adaptation also presented eight frequency options opposed to the five options in the original survey (allowing for frequency measurement over a longer period of time). For the present study respondents had to choose from eight options ranging from "everyday (1), almost everyday (2), one to two times a week (3), twice a month (4), once a month (5), once every three months (6), once every six months (7), to never (8)". It is important to note that a high score indicated a lower frequency of use.

Section B of the measurement instrument consisted of two questions relating to internet shopping. The first question was a dichotomous, single response question to determine whether respondents have purchased online before. The second question assessed respondents' likelihood to purchase online using a 5-point rating scale with (1) representing "very unlikely" and (5) representing "very likely". This question was drawn from a study by Kim and Stoel (2005) in determining customer expectations of online retailers. The question was adapted to a 5-point rating scale compared to the original 7-point rating scale, mainly to simplify the options available.

The final section of the questionnaire included sociodemographic questions such as year of birth, gender, home language and Faculty in which registered. No Cronbach alphas were calculated since no sub-scales were used and all questions represented single response questions of nominal nature.

\section{Data analysis}

The data was captured in SPSS by the fieldworkers, after which the data sets were combined into one data set by the researchers, checked and results analysed. Hypotheses were tested at a five percent level of significance. For Hypotheses 1 and 2 the Wilcoxon Signed Ranks test was used. This test is designed for use with repeated measures and is the nonparametric alternative to the repeated measures $t-$ test. As the data did not show a normal distribution, the Wilcoxon test was appropriate and relevant when respondents are matched on specific criteria. For Hypotheses 3 and 4, the Mann Whitney $U$ test was used as the non-parametric alternative to the twosample t-test as the normality assumption was violated.

\section{RESULTS AND DISCUSSION}

The sample of 1298 was slightly dominated by females (56\%). The distribution of age groups was as follow: $18-19$ year olds (25\%); $20-21$ year olds $(48 \%)$; and $22-24$ year olds $(27 \%)$. The language groups consisted of $29 \%$ Afrikaans-speaking respondents, $30 \%$ English-speaking respondents, 37\% African language speakers and four percent other languages such as German, Spanish, Portuguese and Chinese.

TABLE 1: FREQUENCIES OF MEDIA TYPE CONSUMPTION ( $\mathrm{N}=1298)$

\begin{tabular}{|l|l|c|c|c|c|c|c|}
\hline \multicolumn{2}{|l|}{ Frequency of media type usage } & $\begin{array}{c}\text { Watch tele- } \\
\text { vision }\end{array}$ & $\begin{array}{c}\text { Listen to } \\
\text { radio }\end{array}$ & $\begin{array}{c}\text { Read maga- } \\
\text { zine }\end{array}$ & $\begin{array}{c}\text { Read news- } \\
\text { paper }\end{array}$ & $\begin{array}{c}\text { Use Inter- } \\
\text { net }\end{array}$ & $\begin{array}{c}\text { Use cell } \\
\text { phone }\end{array}$ \\
\hline \multirow{2}{*}{ Every day } & $(\mathrm{N})$ & $(503)$ & $(517)$ & $(33)$ & $(89)$ & $(424)$ & $(1136)$ \\
& $\%$ & 37,9 & 38,4 & 2,3 & 6,4 & 31,3 & 84,3 \\
\hline \multirow{2}{*}{ Almost every day } & $(\mathrm{N})$ & $(377)$ & $(288)$ & $(90)$ & $(195)$ & $(435)$ & $(146)$ \\
& $\%$ & 28,2 & 21,4 & 6,7 & 14,6 & 32,8 & 10,9 \\
\hline \multirow{2}{*}{ 1 to 2 times a week } & $(\mathrm{N})$ & $(252)$ & $(290)$ & $(377)$ & $(457)$ & $(354)$ & $(47)$ \\
& $\%$ & 18,7 & 21,6 & 28,4 & 34,0 & 26,5 & 3,6 \\
\hline \multirow{2}{*}{ Twice a month } & $(\mathrm{N})$ & $(76)$ & $(107)$ & $(335)$ & $(235)$ & $(79)$ & $(6)$ \\
& $\%$ & 5,6 & 8,0 & 24,9 & 17,8 & 6,0 & 0,5 \\
\hline \multirow{2}{*}{ Once a month } & $(\mathrm{N})$ & $(45)$ & $(59)$ & $(265)$ & $(184)$ & $(23)$ & $(0)$ \\
& $\%$ & 3,1 & 4,4 & 19,8 & 13,8 & 1,8 & 0,0 \\
\hline \multirow{2}{*}{ Once every 3 months } & $(\mathrm{N})$ & $(39)$ & $(39)$ & $(127)$ & $(72)$ & $(12)$ & $(6)$ \\
& $\%$ & 2,9 & 2,9 & 9,4 & 5,4 & 0,9 & 0,5 \\
\hline \multirow{2}{*}{ Once every 6 months } & $(\mathrm{N})$ & $(15)$ & $(10)$ & $(63)$ & $(52)$ & $(2)$ & $(4)$ \\
& $\%$ & 0,9 & 0,7 & 4,6 & 3,9 & 0,2 & 0,3 \\
\hline \multirow{2}{*}{ Never } & $(\mathrm{N})$ & $(37)$ & $(35)$ & $(52)$ & $(55)$ & $(9)$ & $(6)$ \\
& $\%$ & 2,7 & 2,6 & 3,8 & 4,0 & 0,7 & 0,5 \\
\hline
\end{tabular}

Note: The bold print indicate the highest frequency reported for each media type 


\section{Media usage by young adult consumers}

As mentioned in the literature review, many believe that young adults have shifted some of their media usage to new media. Therefore, the first hypothesis suggests that young adult consumers use new media more frequently than traditional media. Table 1 provides the frequencies of respondents' media usage.

In terms of traditional media types, Table 1 shows that approximately $38 \%$ of respondents listen to radio every day, more than $37 \%$ of respondents watch television every day, and slightly more than six percent of the respondents read newspapers every day. The results indicate higher new media usage with a daily cell phone usage of $84 \%$ and a total of $31 \%$ for the internet.

If one calculates respondents' frequency of media type usage for a period of a week or shorter, respondents use new media types (both the internet and cell phones) more often than the traditional media types (television, radio, newspaper and magazine). Within a period of a week, cell phones are used $98 \%$ of the time followed by the internet with $90 \%$. Thereafter traditional media follows with broadcast media (84\% television viewership, $81 \%$ radio listenership) and then print media $(55 \%$ newspaper and $37 \%$ magazine readership). The frequencies are in line with some opinions that young adults have shifted some of their television-viewing time to the internet (Wolburg \& Pokrywczynski, 2001; Calisir, 2003). The descriptive results are also in line with estimates that young adults are less likely to read newspapers or magazines, believing that there are quicker and better ways to stay informed (Bridge, 1995; Ashill and Yavas, 2005). Some previous studies on traditional media types report that young adults represent a small percentage of newspaper and magazine readership and will turn instead to radio and television (Stepp, 1996; Dotson \& Hyatt, 2005).
On face value respondents seem to use new media types more often as compared to traditional media types. Table 2 shows the result of the hypothesis test to determine whether differences between traditional and new media usage are significant.

From Table 2 it is clear that the null hypothesis is rejected and that there is support for Hypothesis 1 $(p=0,000)$ based on the results of the Wilcoxon Signed Ranks test result ( $z$-value $=-29,284$ ) indicating that consumers use new media more frequently than traditional media. When interpreting the results in Table 2, it is important to note that a higher score on the measurement scale $(651,58)$ represents lower media type usage and that a lower score on the measurement scale $(268,96)$ indicates a higher level of media type usage. The findings seem to support the views that new media appears to be the media of choice by young adult consumers with findings from other studies reporting that using the internet to obtain information was the most popular form of media used by the respondents (Pasek et al, 2006) and that the cell phone is to become the most influential medium for marketing (Hanley \& Becker, 2008). The study did not investigate reasons for the differences in usage patterns between new and traditional media. Follow-up research is needed to determine whether usage patterns are related to media credibility, or if new media allows individuals to obtain information on specific brands more readily opposed to traditional media.

Use of the internet and printed media by young adult consumers

Findings from some previous international studies indicated that consumers are exposed to the internet more frequently than they are to print media channels (magazines and newspapers). The study consequently hypothesised that young adult consumers browse the internet significantly more than they read print media. Reference to Table 1 shows high daily

TABLE 2: HYPOTHESIS 1 - WILCOXON SIGNED RANKS TEST RESULT

\begin{tabular}{|l|r|r|r|r|}
\hline \multicolumn{1}{|c|}{ Media groups } & N & Mean Rank & \multicolumn{1}{c|}{$\begin{array}{c}\text { Sum of } \\
\text { Ranks }\end{array}$} & $\begin{array}{c}\text { Wilcoxon } \\
\text { Signed Ranks } \\
\text { test }\end{array}$ \\
\hline Frequency of new media < Frequency of traditional media & 1188 & 651,58 & 774073 & \\
\hline Frequency of new media > Frequency of traditional media & 71 & 268,96 & 19096 & \\
\hline Frequency of new media = Frequency of traditional media & 39 & & & $-29,284$ \\
\hline Z-value (based on positive ranks) & \multicolumn{5}{|l|}{} & & $\mathbf{0 , 0 0 0}$ \\
\hline p-value & \multicolumn{5}{|l|}{}
\end{tabular}

TABLE 3: HYPOTHESIS 2 - WILCOXON SIGNED RANKS TEST RESULT

\begin{tabular}{|l|r|r|r|r|}
\hline Media groups & N & Mean Rank & \multicolumn{1}{|c|}{$\begin{array}{c}\text { Sum of } \\
\text { Ranks }\end{array}$} & $\begin{array}{c}\text { Wilcoxon } \\
\text { Signed Ranks } \\
\text { test }\end{array}$ \\
\hline Frequency of print media < Use of Internet & 125 & 290,02 & 36252 & \\
\hline Frequency of print media > Use of Internet & 1081 & 639,75 & 691569 & \\
\hline Frequency of print media = Use of Internet & 86 & & & \\
\hline Z-value (based on negative ranks) & & & & $-27,146$ \\
\hline p-value & & & 0,000 \\
\hline
\end{tabular}


internet usage $(31 \%)$ compared to daily newspaper and magazine usage $(6 \%$ and $2 \%)$.

Table 3 reveals the results of a comparison of frequency of use of media using the Wilcoxon signed ranks test.

The results in Table 3 indicate that there is a significant difference in the usage of print media versus internet $(p=0,000)$. Mean ranking values in Table 3 indicate that young adult consumers' use of the internet is significantly higher than their usage of print media $(290,02$ versus 639,75$)$ - as a lower score on the measurement scale represents a higher media type usage. There is thus support for Hypothesis 2 (null hypothesis is rejected) indicating that young adult consumers use the internet more frequently than print media. Findings from a web survey among young Turkish consumers indicated that print media are less reliable sources compared to the internet (Calisir, 2003). Although the aim of this study was not to uncover the reasons for high or low usage of a particular media type, one can speculate whether reliability or credibility of a media type may have had an influence on the low print media usage reported in the study. On the other hand, a study among Turkish and New Zealand respondents indicated that young adult consumers rate print media as important information sources and convenient buying guides (Ashill \& Yavas, 2005), emphasising the importance of follow-up research to determine the reasons for media usage patterns.

Online purchasing and the likelihood of online purchasing by young adult consumers

It has been suggested that as one's use of the internet increases, the likelihood to buy via the internet also increases. One could argue that if young adult consumers prefer new media types to traditional media types, they will exhibit a high propensity to purchase online. Findings, however, reveal the contrary: the majority of respondents $(72 \% ; n=1298)$ have never purchased online before. This low activity in terms of online purchasing could partly be attributed to the lack of credit card possession amongst students as a credit card is a pre-requisite for purchasing online.

Respondents' likelihood to shop online in the next twelve months ranged from very unlikely $(44,2 \%)$, unlikely $(21,6 \%)$, neutral $(15,3 \%)$, likely $(11,7 \%)$ to very likely $(7,2 \%)$. These low likelihood percentages show that most of the respondents do not foresee that their near future online shopping behaviour will change. However, given the notion that likelihood to purchase online will increase as internet usage increases, one assumes that those who have purchased online and those who have not purchased online, will differ in their intent to purchase online in the future. Therefore, the third hypothesis states that young adult consumers who have shopped online and those who have not shopped online with regard to their likelihood to purchase online will differ significantly.
The result of the Mann Whitney test indicated a $p$ value of 0,000 ( $z$ value $=\square 13.694$ ) showing support for Hypothesis 3 (rejecting the null hypothesis). The mean ranking values also indicate that those who have purchased online before show a higher likelihood to shop online in the next twelve months $(852,15)$ than those who have not purchased online before $(554,39)$. This finding correlates with another local study's research finding that the longer a person uses the internet, the more likely he/she becomes to buy online (Du Plessis et al, 2004). From the literature review it is evident that the internet as a shopping channel is being explored by an ever-increasing number of young adult consumers. Also, international research findings show that young adults' buying habits are influenced more by the internet than any other media (Wolburg and Pokrywczynski, 2001).

Young adult male and female consumers as internet buyers

As mentioned in the literature review, several previous studies report gender differences in online purchase behaviour (Akhter, 2003; Janda, 2008). For this study, of those respondents $(n=363)$ who have purchased online before, $53 \%$ were females and $47 \%$ were males. Those who have never purchased online before $(n=935)$ consisted of $57 \%$ females and $43 \%$ males. The last hypothesis aimed to determine if gender groups differed significantly in their online shopping likelihood.

The Mann Whitney test indicated that the null hypothesis should be rejected since a p-value of 0,000 (z-value $=-4,313$ ) is reported, thus showing support for Hypothesis 4. The mean ranking values (male: 695; female: 609) suggest that males show a higher online shopping likelihood than females. This finding supports the findings from another South African study that indicated that internet buyers are more likely to be male (Du Plessis et al, 2004). Possible reasons for female respondents' lower likelihood to purchase online may be attributed to their high risk perceptions of online shopping (Janda, 2008), as well as the reduced social experience in an online shopping environment (Bakewell \& Mitchell, 2003). On the other hand, the internet may provide males with a quick, convenient and easy to access shopping option (Maciejewski, 2004), that are also interesting in terms of employing different technologies during the shopping process (Y Monsuwe' et al, 2004). Worth noting is that shopping likelihood and actual shopping behaviour are different concepts and more research is needed to determine actual shopping behaviours of young adult consumers.

\section{MANAGERIAL IMPLICATIONS AND RECOMMEN- DATIONS}

Results indicate that young adult consumers use new media significantly more often than traditional media. This may be attributed to the fact that new media offers a variety of online channels through which young adults can socialise and communicate such as email, blogging, twitter and social networks (such as Facebook, MySpace, YouTube and Linkedln). New media 
therefore requires marketers to use additional mediums in their communication to young adults. One example is the mobile platform which offers huge potential as South Africa rates sixth in the world in terms of accessing the web using cell phones (Duarte, 2009). South Africa's youth are also amongst the fastest-growing users of cell phones with an increase in demand for cell phone applications such as MXit and MP3 (Botha, 2004; Youth Dynamix, 2009). The development of mobile social networking has led to 14 million registered international MXit users which is popular among the under 25 year olds (Heunis, 2009).

The results from this study confirm previous findings of Barnikel (2005) that indicate that young adult consumers browse the internet significantly more frequently than they read print media. This result could have been influenced by the fact that respondents in this study were all full-time students at the time of completing the questionnaire. It is quite feasible that their studies require they use the internet more frequently to obtain information for the completion of assignments. The high frequency of internet usage reported is unlikely to resemble the total population and can possibly be ascribed to the availability of internet facilities on campus. However, many believe that the internet has become a medium of choice for young adult consumers, with South Africa reporting around 5.5 million internet users (Robinson, 2009).

There is a significant difference between individuals who have shopped online and those who have not shopped online with regard to their likelihood to shop online. However, the majority of respondents have never purchased online before, showing that even though the online shopping trend is growing in South Africa (Packree, 2007), the country is still lagging behind their American and European counterparts. Of the few respondents who have experienced online shopping, a higher online purchasing likelihood was displayed. This may be because they have experienced the advantages of this shopping channel first hand in terms of saving time, eliminating transport costs, eliminating congestion and queues, and anonymity (Ashill \& Yavas, 2005; McClatchey et al, 2007). An increase in online transactions from young adult consumers in the US are reported (Devaraj et al, 2006) highlighting the potential of the internet as a shopping alternative for young adult consumers.

This study suggests that marketers should approach the move from traditional means of selling products and services to the selling of products and services online cautiously. This is especially apparent when targeting these young adult consumers, considering that the findings show that $72 \%$ of respondents do not purchase online. An organisation wanting to sell their products online would have to educate consumers in terms of online purchasing and/or adapt to the needs of the young adult market. For example, the lack of credit cards in the 14 to 24 age group (Goldstuck, 2009) calls for a virtual cash environment that will give credit card-less individuals the ability to make purchases online. One such initiative is MiMoney which is a real electronic currency that can be utilised to make purchases at selected online retailers (Goldstuck, 2009). Young adult consumers may also need to be informed of the advantages of online shopping, while also addressing non-internet users' concerns or scepticism in terms of security and privacy through online privacy policy protection ( $\mathrm{Xu} \&$ Paulins, 2005).

The results suggest that male consumers are more likely to purchase online than female respondents in the next twelve months which concur with findings from other researchers (Bakewell \& Mitchell, 2003; Du Plessis et al, 2004; Y Monsuwe' et al, 2004). Shopping behaviour and styles among genders play a significant role in online shopping. Bakewell and Mitchell (2003) stated that females enjoy the process of shopping and are happier to spend more time and energy in shopping centres, as opposed to males who are more likely to buy quickly and avoid shopping trips as much as possible. Situation specific research might be needed to determine whether gender differences are significant for specific products or services.

Marketing managers need to look beyond mere consumption patterns when communicating to young adult consumers. Utilising media which these consumers regularly consume (new and broadcast media) may be effective in generating awareness of new products or marketing efforts. These media may not, however, be as successful in effecting attitude or perception changes among these consumers. Results indicate that gender differences, as well as shifting usage patterns are some of the key factors to consider when dealing with members of the young adult group.

\section{LIMITATIONS AND DIRECTIONS FOR FUTURE RESEARCH}

Since use was made of non-probability sampling, results from this study can not be generalised to the broader population. The study also solely focused on students, who may have significantly different media habits and perceptions of online shopping than other young adult consumers who are working. It is recommended that this study be replicated among a broader spectrum of young adult consumers (working and non-working) across South Africa to increase representativeness. It may also be valuable to conduct research in the 25 to 30 year old group to establish whether they behave significantly different from the respondents in this study.

Possible reasons for the low online shopping likelihood should be investigated in future studies combined with the implications of the internet as a shopping channel within a South African context. This may assist online vendors to determine whether it is truly feasible to advertise online in South Africa. The relationship between credit card ownership and online shopping purchases or intent could also be investigated. The study did not aim to investigate reasons for the differences in usage patterns between new and traditional media which could be a focus of a follow-up study. Future research could also focus on the relationship between usage patterns and media credi- 
bility. In a country that is diversely populated with many different ethnic groups, one could expand this study and determine whether different cultures or ethnic groups differ in their media usage and internet exposure. Comparative studies between developing and developed countries in terms of media usage and perceptions are also recommended.

\section{CONCLUSION}

It is trusted that the findings of this research will assist marketers to make informed decisions on targeting young adult consumers. Considering the rate at which technology is growing, the world will be more reliant on information technology and communication in the future. Although message content was not evaluated in this study, it is an important factor to consider. Morton (2002) speculated that it is not so much the media vehicle that matters, but rather the nature of the message. Persuasive messages might be communicated more effectively through credible traditional media channels, while new media types might work better for reminders, newsflashes or information about events, especially since young adult consumers are highly reachable through these mediums. New media can also be used to strengthen messages delivered through traditional media. This study should provide a better understanding of the media habits and usage of this segment, and pave the way for meaningful future research in this regard.

\section{REFERENCES}

AHONEN, T. 2008. Mobile as the $7^{\text {th }}$ of the mass media: cellphone, cameraphone, iphone, smartphone. Futuretext. London.

AKHTER, SH. 2003. Journal of Economics Psychology 24(2003): 321-327.

ALCH, ML. 2000. The Echo-Boom Generation: A growing force in American society. The Futurist 35 (5):42.

ANDERSON, LP, TUFTE, B, RASMUSSEN, J \& CHAN, K. 2007. Tweens and new media in Denmark and Hong Kong. Journal of Consumer Marketing 24 (6):340-350.

ASHILL, NJ \& YAVAS, U. 2005. Importance of information sources and media evaluations: A crossnational study. International Journal of Cross Cultural Management 12(4):51-62.

BAKEWELL, C \& MITCHELL, VM. 2003. Generation $\mathrm{Y}$ female consumer decision making styles. International Journal of Retail and Distribution Management 31(2):95-106.

BARNIKEL, M. 2005. Gen Y media habits show tide is turning in favour of internet. Media 20 May:12.

BERNDT, A. 2007. Media habits among Generation $Y$ consumers. In: Du Toit, A.S.A (ed). Proceedings of the 19th Annual Conference of the Southern African Institute of Management Scientists, Johannesburg, South Africa, 19-21 September 2007.

BOTHA, E. 2004. Cellophone use among SA's youth increases. Daily Dispatch 31 March:4.

BRIER, NR. 2004. Move over, prime-time! American Demographics 26(6):14-19.

BRIDGE, J. 1995. Young adults are stereo-typed by the media. The Quill 83(1):13.
CALISIR, F. 2003. Web advertising vs. other media: young consumers' view. Internet Research: Electronic Networking Applications and Policy 13(5):356-363.

CHAN, K \& FANG, W. 2007. Use of the internet and traditional media among young people. Young Consumers: Insight and ideas for responsible marketers 8 (4): 244-256.

CHESTER, J \& MONTGOMERS, K. 2008. No escape. Marketing to kids in the digital age. Multinational Monitor 30(1): 11-16

CROSMAN, P. 2008. Attracting young investors financial firms are embracing mobile technology, Web 2.0 tools and social networking principles to reach Gen X and Gen Y. Wall Street and Technology 26 (1):16.

DEVARAJ, S, FAN, M \& KOHLI, R. 2006. Examination of online channel preference: Using the structure-conduct-outcome framework. Decision Support Systems 42(2):1089-1103.

DOTSON, MF \& HYATT, EM. 2005. Major influence factors in children's consumer socialisation. Journal of Consumer Marketing 22(1):35-42.

DU PLESSIS, PJ, MOSTERT, PG \& NORTH, EJ. 2004. Period of Internet usage: An indicator of the buying behaviour of Internet users South African Journal of Economic and Management Sciences, 7 (1):75-88.

DUARTE, D. 2009. Local mobile marketing course gets global insights. Biz-community, 29 June: 1.

FARRIS, R, CHONG, F \& DUNNING, D. 2002. Generation $Y$ : purchasing power and implications for marketing. Academy of Marketing Studies Journal 6 (2):89-100.

FOX, S. 2005. Generations online. Pew Internet \& American Life Project. URL: http:// www.pewinternet.org/PPF/r/170/report_display.asp [Accessed 21 August 2008].

GOLDSTUCK, A. 2009. Online shopping for the credit card-less. Biz-community, 6 July:1.

HANLEY, M \& BECKER, M. 2008. Cellphone usage and advertising acceptance among college students: a four year analysis. International Journal of Mobile Marketing 3(1):67-80.

HEUNIS, H. 2009. MXit achieves over 14 million users. Biz-community, 15 July:1.

HOST, A. 2005. Reaching the Millenials: A study of the use and effectiveness of new media. Unpublished senior honors thesis project. Ball State University Muncie. Indiana.

JANDA, S. 2008. Does gender moderate the effect of online concerns on purchase likelihood? Journal of Internet Commerce 7(3): 339-358.

JIN, CH \& VILLEGAS, J. 2008. Mobile phone users' behaviours: the motivation factors of the mobile phone user. International Journal of Mobile Marketing 3(2):4-80.

KENNEDY, G, KRAUSE, K, GRAY, K, JUDD, T, BENNET, S, MATON, K, DALGARNO, B \& BISHOP, A. 2006. Questioning the net generation: A collaborative project in Australian higher education. Proceedings of the $23^{\text {rd }}$ Annual Conference on the Australian Society for Computers in Learning in Tertiary Education: Who's learning? Whose technology?, Sydney, Australia, 3-6 December:

KILGER, M \& ROMER, E. 2007. Do measures of media engagement correlate with product purchase like- 
lihood. Journal of Advertising Research 47(3):313325.

KIM, M \& STOEL, L. 2005. Salesperson roles: are online retailers meeting customer expectations? International Journal of Retail \& Distribution Marketing 33 (4):284-297.

KING, K. 2006. Youth - lifestyle, expectation and media. Young Consumers: Insight and ideas for responsible marketers 7(2): 22- 29.

KORGAONKAR, P \& WOLIN, LD. 2002. Web usage, advertising and shopping: relationship patterns. Internet research: Electronic Applications and Policy 12 (2): 191-204.

KREUTZER, T. 2009. Internet and online media usage on mobile phones among low-income urban youth in Cape Town. Pre-conference workshop at the International Communication Association (ICA) conference, Chicago Illinois, USA, 1-21 May 2009.

KUHLMEIER, D \& KNIGHT, G. 2005. Antecedents to internet-based purchasing: a multinational study. International Marketing Review 22(4): 460-473.

MACIEJEWSKI, JJ. 2004. Is the use of sexual and fear appeals ethical? A moral evaluation by generation y college students. Journal of Current Issues and Research in Advertising 26(2):97-99.

MANGLEBURG, TF \& BRISTOL, T. 1998. Socialization and adolescents' skepticism toward advertising. Journal of Advertising 27(3):11-21.

MCCASTLAND, M. 2005. Mobile Marketing to Millennials. Young Consumers: Insight and ideas for responsible marketers. 6(3): 8-13.

MCCLATCHEY, J, CATTELL, K \& MITCHELL, K. 2007. The impact of online retail grocery shopping on retail space: A Cape Town case study. Facilities 23 (3/4):115-126.

MOORE, JJ \& RODGERS, SL. 2005. An examination of advertising advertising credibility and skepticism in five different media using the persuasion knowledge model. Proceedings of the 2005 American Academy of Advertising Conference, Michigan State University, USA, January.

MORTON, LP. 2002. Targeting Generation Y. Public Relations Quarterly, 47(2):46-48.

NAPOLI, J \& EWING, MT.1998. The media habits and internet practices of the net generation. Proceedings of the 1998 ANZMAC Conference, University of Otago, Dunedin, New Zealand, 30 November-2 December:

NEWTON, S. 2009. Importance of getting online during the downturn. Biz-community 10 July: 1.

PACKREE, S. 2007. Switch to online ordering avoids hassles of traditional shopping. Daily News 10 January:2.

PASEK, J, KENSKI, K, ROMER, D \& JAMIESON, $\mathrm{KH}$. 2006. America's youth and community engagement: How use of mass media is related to civic activity and political awareness in 14-to-22-yearolds. Communication Research 33(3):115-135.

ROBINSON, A. 2009. Mobile marketin drives creativity. Biz-community 1 July: 1.

SOUTH AFRICAN BROADCASTING CORPORATION (SABC). 2007. Young South Africans, broadcast media, and HIV/Aids awareness: Results of a national survey - March 2007. The Henry J. Kaiser family foundation. [Online] Available from: http:// www.kff.org/southafrica/upload/7614.pdf [Downloaded: 2008-05-19].

SEOCK, Y-K \& CHEN-YU, JH. 2007. Website evaluation criteria among US college student consumers with different shopping orientations and Internet channel usage. International Journal of Consumer Studies 31:204-212.

STEPP, C. 1996. The X Factor. American Journalism Review 18(9):34-38.

STRAUBHAAR, JD \& LAROSE, R. 2006. Media Now: Understanding media, culture and technology. $5^{\text {th }}$ ed. Thompson Learning. Australia.

SZETO, C. 2005. The impact of age, generation and life stage on the use of mail and media. Pitney Bowes research project 11 (July 13):1-20.

WELDON, Q. 2009. The global teen and South Africa. Biz-community 9 June:1.

WOLBURG, JM \& POKRYWCZYNSKI, J. 2001. A psychographic analysis of Generation $Y$ college students. Journal of Advertising Research 41(5):33-52. WYNER, GA. 2007. Face the media future. Expect more uncertainty and plan to deal with it. Marketing Management 16(2): 8-9.

XU, Y \& PAULINS, VA. 2005. College students' attitudes toward shopping online for apparel products. Journal of Fashion Marketing and Management 9 (4):420-433.

$Y$ MONSUWE', TP, DELLAERT, BGC \& DE RUYTER, K. 2004. What drives consumers to shop online? A literature review. International Journal of Service Industry Management 15(1):102-121.

YOUTH DYNAMIX. 2009. BratTrax the hottest youth study to hit South Africa this year. Biz-community 14 January:1.

YOUTH INC. 2000-2001. Youth Inc. Economist 357 (8202):9-10. 